\title{
CHANGING ORGANIZATIONAL CULTURE: PELAJARAN UNTUK AKTOR PERUBAHAN BUDAYA DAN PIHAK LAIN
}

\section{Burhanudin Mukhamad Faturahman}

Akhir bab ini mengulas tentang isu-isu praktis yang mempunyai relevansi bagi para praktisi terhadap manajemen perubahan yaitu manajer tingkat atas dan menengah, konsultan manajemen, staf perekrutan sumberdaya, dan lainnya. Bagian ini lebih mengarah pada tema pengrefleksian dan mendorong cara berpikir perangkap yang mungkin terjadi serta kompleksitas dari perubahan kerja. Bab ini ada tiga bagian yaitu pertama, konsentrasi pada perangkap yang kemungkinan bisa terjadi: hyperculture, simbol anorexia , fokus yang berlebihan mengenai nilai-nilai dan penyangkalan terhadap ketidaktahuan. Kedua, mengarah pada sebuah gambaran mengenai program-program perubahan yang dilakukan oleh berbagai aktor (perubahan pada proyek baik yang bersifat umum maupun khusus). Ketiga, mencoba menawarkan pembelajaran tidak hanya keluar dari perangkap tetapi juga tema tentang perhatian yang lebih (Alvesson and Sveningsson 2008).

\section{Perangkap Yang Potensial dalam Budaya Organisasi}

\section{Hyperculture}

Poin dari hyperculture adalah orang-orang menganggap cara bekerja dalam lingkungan organisasi merupakan duplikasi dari orang lain yang pernah melakukan hal yang serupa sehingga kesadaran dari diri sendiri belum muncul karena kegiatan yang akan dilakukannya merupakan hak dengan kata lain inisiatif dari diri sendiri sebagai kewajiban dalam melaksanakan setiap pekerjaannya sehingga perlu membuat standarisasi mengenai pengenalan nilai-nilai. Masalahnya efek dari hyperculuture ini dapat memutus hubungannya dari konteks organisasi yang seharusnya dituju. Hal ini memberikan pentingnya pemahaman mengenai budaya yang ideal dan pembendaharaan kata agar tidak terpisahkan di tingkat simbolis, bersamaan dengan itu dijadikan sebagai prioritas yang lebih dalam kegiatan organisasi. Masalah tambahan dapat berupa sejumlah persyaratan tambahan yang begitu luas dan multidimensi jika suatu organisasi ingin mencapai banyak proyek-proyek perubahan. Sementara hyperculture lebih mudah bagi para konsultan dan spesialis komunikasi untuk 
membuat dokumen berdasarkan kosa kata lokal dan membuat tema yang konkret untuk menangkap unsur-unsur budaya dalam organisasi untuk dirumuskan.

\section{Simbol Anorexia}

Isu kunci lainnya dalam kebanyakan organisasi lainnya yaitu masalah (kekurangan) keragaman simbol dalam perubahan kerja yang biasa disebut anorexia. Budaya sebagai makna kebersamaan dan simbol merupakan sebuah konsep untuk meringkas dan mengungkap makna dan cara. Simbol dapat berupa peristiwa, tindakan, bahan objek, ekspresi dan cerita. Ini mengindikasikan tidak hanya menggunakan otak saja tetapi juga emosi dan fantasi dalam perubahan kerja. Sebuah simbol bisa dimunculkan dengan pendahulu/tokoh yang sukses mengangkat kinerja organisasi dan karena keberhasilannya itulah tokoh tersebut ditakuti; lokakarya untuk membingkai sebuah pesan yang konsisten antar sosial dan interaksi umum; ataupun pesan dari pimpinan tentang kepercayaan dan komitmen (meski tidak semua orang karismatik tapi pesan dari para pendahulu yang berhasil menciptakan sebuah nilai tersendiri).

\section{Keterbatasan dari Nilai-Nilai}

Berbicara masalah nilai dalam organisasi merupakan unsur yang penting yaitu mengenai nilai-nilai relevan yang diperlukan dalam perubahan dan budaya organisasi. Nilai biasanya dibingkai berupa nilai yang terdengar baik (kadang-kadang buruk) dan terlalu mudah untuk setuju dengan hal-hal yang baik (dan tidak setuju dengan yang buruk). Permasalahan justru nampak pada hubungan antar konflik yang baik kemudian diurutkan (diatur) agar fokus pada nilai tertentu tidak mudah hilang. Contoh: orientasi pada pelanggan tapi tidak mengilangkan orientasi teknologi, orinetasi peningkatan kepemimpinan tapi tidak menghilangkan perhatian pada karyawan non manajer (kurang status, kurang sumberdaya pengembangan, dan lainnya)

Sebuah nilai jika dilihat lebih jauh adalah bagaimana memaknainya (aspek makna). Melihat seorang pelanggan tidak hanya dari kategori saja tetapi lebih kepada definisi pelanggan dan apa arti dibalik orientasi pada pelanggan tersebut. Kepemimpinan juga penting dalam perubahan organisasi entah itu hanya sekedar melakukan aktivitas yang ringan semisal percakapan kecil dengan para karyawan yang menunujukkan minatnya dalam sebuah pengambilan keputusan. Sebagai pemimpin seharusnya bisa mengambil makna 
penting dari nilai dan lebih memperhatikan makna yang terkandung dan harus mendahulukan nilai tersebut. Hal lain yang perlu diperhatikan dalam memaknai dan pengertian daripada nilai adalah manajerialisme dan birokrasi yaitu tentang hubungan manusia dengan orgnisasi. Tentu saja ini tidak hanya menyangkut masalah manusia menghargai prinsip organisasi untuk diikuti. Fokus terhadap fenomena budaya, makna dan keyakinan dapat dipahami sebagai hal yang baik dan hasilnya mengarah ke hasil yang positif berupa nilai

4. Bekerja dengan budaya dalam konteksnya daripada kami

Perubahan budaya dalam organisasi melibatkan seluruh anggota organisasi tak terkecuali kelompok-kelompok yang memikirkan proses perubahan tersebut terkait prinsip baru dalam bentuk asumsi, nilai dan ide. Nilai baru yang diterapkan dari hasil perubahan dapat juga bermanfaat bagi organisasi yang telah dilakukan perubahan sebelumnya untuk memperbaiki organisasi mereka sendiri. Dengan kata lain perubahan budaya juga merubah kelompok dalam organisasi beserta "bekas" organisasi yang mengalami perubahan sebagai perbaikan atas dirinya sendiri. Perubahan bersifat transformasi kolektif dan menempatkan tanggungjawab untuk mendorong perubahan. Oleh karena itu mendorong perubahan juga mendorong diri kita senditi untuk berubah, ide bisa muncul seputar hierarki, teknokratik, mengubah pekerjaan, dan lain-lain.

5. Keterbatasan pengetahuan

Aktor kunci dalam perubahan selayaknya memiliki pengetahuan yang cukup tentang perubahan yang terjadi. Jangan sampai kepercayaan diri membawa kebodohan atau aktor kunci tersebut kekurangan informasi. Konsultan yang masih dipercaya sampai saat ini yaitu manajemen tingkat atas dari perekrutan karyawan yang ahli perubahan budaya. Seorang pemimpin dalam menerapkan gaya kepemimpinannya tidak dipahami oleh sebagian besar karyawannya karena organisasi tersebut hyperculutre sehingga perlu pengetahuan dalam organisasi secara menyeluruh.

Masalah kekurangan pengetahuan adalah masalah yang selalu ada dalam organisasi namun kegiatan indentifikasi dengan cara mendengarkan cerita dalam organisasi akan membantu. Menerapkan kesopanan, keingintahuan, membuka fungsi umpan balik dan kritik, memerikasi sejauh mana perubahan akan ditargetkan untuk perbaikan dan mengurangi kemungkinan proyek perubahan abal-abal (tidak bermakna).

\section{Gambaran Dasar Dari Perubahan}


Pertanyaan kunci dari proyek perubahan adalah bagaimana semua orang bisa berperan aktif dalam pekerjaan dan memahami sifat dasar dari proyek seperti tujuan, atau prosedur pemikiran. Sebuah gambaran perubahan dapat dilihat dua dimensi salah satunya kontrol dari manajer atau kontribusi dari manajer. Sisi yang lainnya yaitu hasil dari tiga posisi yang diidentifikasikan: dapat diprediksi, sebagian diprediksi dan tidak terduga. Kemudian menunjukkan enam gambaran dasar: direktur, navigator, pengurus, pelatih, penerjemah, dan pemelihara.

Perubahan yang utama lebih menekankan pada tanggungjawab manajer dalam menjalankan proyek. Tapi ada penekanan lain yaitu sifat kolektif dari perubahan kerja dan pandangan dari target perlu diperhatikan serius. Perubahan organisasi sering muncul perubahan yang direncanakan, atau muncul inkremental ataupun radikal sehingga perlu diatasi sifat dari perubahan tersebut secara objektif. Oleh karena itu diperlukan penyesuaian pemahaman dan intergrasi dan identitas organisasi. Seringkali makna perubahan oleh kelompok-kelompok orang memiliki banyak pemikiran tentang gambaran perubahan sehingga kedua hal tersebut perlu dipertimbangkan (manajer beserta proses perubahan kerja dan persepsi kelompok perubahan)

\section{Transformasi, Membuka Pandangan dan Gelombang}

Gambaran perubahan oleh manajer meliputi transformasi dasar proyek dan membuka pandangan. Keduanya ini memiliki beragam tujuan (1) luas dan radikal dan fungsi-fungsi baru (2) inspirasi pemikirian ulang. Tampilan dinyatakan dari perubahan sebagai gelombang tidak bersangkutan dengan tujuan, tetapi lebih pada seharusnya cara tersebut bekerja. Tindakan yang kuat dan inspiratif dilakukan untuk memulai sebuah gerakan dan pelibatan orang-orang dalam perubahan merupakan sebuah ide untuk mentransfer cara baru berpikir turun dari organisasi dan juga untuk mendorong saran dari bawah. Idenya adalah untuk membuat sejenis gelombang dalam perusahaan terkait komitmen tantangan sebagai komitmen (Aldridge). Gelombang ini semacam perlawanan arus top-down pelaksanaan perubahan dimana inisiatif muncul secara dinamis.

Gambaran membuka pandangan dan gelombang disajikan dalam wawancara setelah program aktif memuat kinerja manajemen puncak terkait tahap perencanaan, mengubah pekerjaan secara aktif, melihat program sebagai proyek transformasi dasar, mengubah unit internal perubahan dan pengembangan dengan orientasi pasar. Lebih bermanfaat lagi dibuat sebuah klarifikasi dari revisi tampilan dasar perubahan. Ide dalam membuka pandangan 
menyebabkan transformasi radikal kurang lebih seperti membebaskan dan menciptakan kembali.

Gambaran ini merupakan yang bertolak dari perubahan yang ditarget seperti:

- Kemunafikan: manajer harus mendorong pekerjaan sebagai budaya yang ada dalam organisasi. Jangan sampai budaya organisasi dalam bekerja ada tetapi karyawan bekerja bekerja tidak mencerminkan kinerja budaya dalam organisasi. Maka manajer berpikir untuk mendorong mereka kea rah budaya dengan perkataan bukan sebagai kelakuan.

- Tunjukkan pada semua orang bahwa budaya organisasi yang baru telah dimiliki sehingga karyawan menciptakan gambaran perubahan tertuju pada substansi dan tidak melenceng dari gambaran ideal organisasi.

Sementara, perubahan diarikan sebagai sesuatu hal yang kosong dan lemah dan bermasalah jika perubahan yang dilakukan tidak sesuai dengan kenyataan. Perihal menciptakan sebuah gambaran perubahan adalah mengatur hubungan manusia dan mengubah program dan komunikasi. Namun gambaran tersebut tidak selalu statis dan koheren karena mengalami beberapa pergeseran. Oleh karena itu alasan yang baik yaitu dengan mensinkronkan kembali pemahaman dari apa yang terjadi dengan mereka yang terlibat. Untuk menciptakan gambaran yang selaras dengan perubahan maka diperlukan aktor kunci yang membantu manajer melaksanakan perubahan sebagai penerjemah dan pendidik perubahan.

\section{Pelajaran yang diperoleh}

Implikasi yang variatif bisa diperoleh dari perubahan organisasi (Bir, 2000) seperti meningkatkan kinerja yang tinggi: koordinasi antar fungsi, kreativitas dalam bidang teknis dan administratif. Heracleous dan Langham (1996) menyarankan perubahan dalam manajemen perubahan yang sukses yakni kepemimpinan yang jelas, komunikasi yang jelas, keterlibatan karyawan dalam tahap perencanaan dan mengembangkan ketrampilan baru. Bir dan Nohria (2000) perubahan yang berhasil terletak pada E - O yaitu berfokus pada kondisi ekonomi dan kemampuan organisasi. 
Pelajaran yang diperoleh secara praktis dari perubahan harus lebih berhati-hati dalam memberikan cara-cara kerja yang berhasil. Seperti para ahli perubahan menyarankan, keberhasilan tidak mudah sehingga penting untuk memperhatkan isu-isu di bawah ini:

Konteks pembingkaian, pengorganisasian perubahan para pekerja, isi, taktik, dan proses.

\section{Konteks Pembingkaian}

1. Transformasi organisasi dimaknai sebagai transformasi diri semua anggota organisasi. Tidak hanya menyangkut masalah para elit yang mengubah tetapi semua orang aktif menyumbang ide-ide, menghindari keyakinan dan asumsi bahwa perubahan telah benar dilaksanakan berasal dari masalah perubahan. Ini adalah asumsi umum perubahan berorientasi pada literatur.

2. Bekerja secara realistis yang mempunyai tujuan dan melanjutkan pengalaman budaya yang ada, mengambil kemajuan yang dapat dicapai kurun waktu dekat. Tujuannya yaitu menghindari kesenjangan yang besar antara cita-cita dan realitas.

3. adanya orientasi yang jauh terkait visi. Etos kerja yang tekun, mendorong variasi ide-ide, cita-cita dan makna mutlak harus ada serta ditunjang upaya yang berkelanjutan.

\section{Pengorganisasian Perubahan Para Pekerja}

4. Perubahan budaya kerja memerlukan integrasi konseptualisasi dan implementasi pekerjaan yang berkelanjutan. Pertimbangan keterlibatan pada proyek biasanya lebih maju dalam perubahan literatur.

5. Penting untuk mengelola dan menjelaskan peran dan hubungan pekerja dengan kegiatan perubahan serta identitas pekerja. Identitas diri diperlukan untuk melihat diri mereka sendiri dalam konteks tertentu dari perubahan dan pemahaman oleh orang lain. Harapan juga harus disesuaikan dengan identitas dan klarifiaksi perbedaan.

6. Penting untuk mengklarifikasi identitas tentang tema pengembangan ketika membicarakan, merevisi dasar program perubahan. Keberhasilan perubahan kerja adalah sejumlah orang yang memiliki pandangan luas dan sama dari pekerjaannya dan dasar tentang pekerjaan.

7. Kebutuhan yang kuat untuk merubah budaya kerja diperlukan jika karyawan bekerja malah seperti di luar organisasi itu sendiri. Menghapus citra negatif perlu karena manajer dinilai sebagai pusat mengubah pekerjaan. 


\section{Konten (Isi)}

8. Perubahan menyangkut isi daripada organisasi itu sendiri. Perubahan budaya kerja merupakan sesuatu yang muncul dari kritik dari beberapa orang dan usulan sesuatu tentang perubahan tersebut. Mempromosikan diri penting terkait kualitas dan cara-cara berbudaya dalam bekerja. Sebaliknya apa yang cenderung mengguncang untuk mendapatkan kesempatan yang lebih baik dalam bekerja dan usaha untuk menjauhi hyperculture.

9. Perubahan menyangkut isi lainnya yaitu fokus pada makna atau paling tidak pada nilainilai. Fokus ini untuk mendorong kreatifitas dan tindakan karyawan. Arah perubahan penting, tetapi fokus pada nilai-nilai lebih mempermudah preferensi dalam mencapai cita-cita bukan sebagai perwujudan hyperculture. Selain itu makna dan pemahaman elemen dasar dari budaya organisasi perlu diklarikasi dengan bertanya"apa yang terjadi di sini ?, apa yang salah dengan tempat ini ?" sebelum usaha mencapai cita-cita. Hal ini bermanfaat dalam membuat kritik pada diri sendiri.

\section{Strategi}

10. Penggabungan dorongan dan dialog. Penggabungan dilakukan dengan memilih kelompok untuk bisa berkontribusi, menyakinkan, mengilhami dan mengingatkan yang dapat mempengaruhi kelompok yang lebih besar (untuk ditarik kembali pelaporan dan mengambil pandangan dari kelompok besar). Pemilihan orang dilakukan untuk mendorong perubahan dan mungkin memerlukan beberapa masukan penting. Dialog penting untuk memperjelas komunikasi terkait visi, strategi, arah perubahan untuk kelompok inti. Untuk masalah interaksi dialog urusan pelaporan, tindak lanjut dan umpan balik, menciptakan dan memberikan perhatian. Omelan juga merupakan bentuk dialog yang penting untuk dialog yang lebih lanjut.

11. Bekerja dengan ketrampilan emosi dan simbolisme. Perumusan pesan penting tidak hanya untuk intelektualitas saja tetapi juga mengatur emosi dan juga imajinasi untuk dijadikan simbol. Penghilangan anorexia penting dalam menciptakan budaya dan fantasi/imajinasi serta menciptakan sikap emosional yang variatif dalam perubahan budaya kerja. Sebuah penargetan gagasan yang melampaui ekspetasi cara bekerja yang normal menunjukkan tingkat yang lebih tinggi untuk dapat dipercaya dan kesempatan 
selalu ada untuk berkembang. Jika hanya mengikuti aliran birokrasi nampaknya tidak efektif untuk proyek perubahan.

\section{Proses}

12. Perhatian penting ditujukan membuat rasa (pengaruh) yang sedang berlangsung di organisasi selama proses perubahan. Penolakan hyperculutre jelas diperkuat untuk menghindari pengulangan rumus yang standar dengan kata lain tidak ada kretifitas yang mencul. Pendorongan makna, ide-ide dengan pengalaman akan lebih baik dalam proses perubahan budaya kerja.

13. Melakukan perhatian penuh pada proses dan penerimaan. Penting untuk menarik perhatian dari para aktor perubahan pada makna dan arti dalam keterlibatan perubahan berbagai usaha. Usaha ini harus diikuti cara pembelajaran dan cara beradaptasi. Perubahan budaya kerja tidak dapat mengikuti keputusan desain rasional karena ada batasan-batasan proses yang dilakukan terhadap perhatian rasional. Untuk itu dibuat model yang ketat dalam membagi perubahan bekerja terkait perencanaan dan masalah implementasi.

14. Menjaga tema budaya dalam agenda. Kerja secara rutin dan teratur merupakan cara untuk menghindari budaya kerja yang mati. Manajer memiliki peran penting dalam agenda dan menjaga budaya kerja agar berkelanjutan dengan cara urutan daftar langkah (langkah berpikir-n). secara konvesional manajer telah siap namun memasukkan unsurunsur upaya perubahan budaya, nilai-nilai, makna tidak nampak dan masih merupakan hal baru. Manajer juga harus bisa melihat trek perubahan, menggabarkan dan memperjelas isu-isu tentang arah perubahan serta memfailitasi perubahan tersebut.

\section{Hasil akhir yang diperoleh}

15. Himbauan hati-hati dalam proyek perubahan nampaknya perlu dicermati karena mitos perubahan selalu menghasilkan hasil yang baik masih memiliki kenyataa yang belum realistis. Target yang dibebankan terlalu banyak dalam perubahan sehingga mengubah seolah menjadi hal yang sulit. Cara yang lebih baik yaitu mengubah perubahan budaya kerja menjadi sebuah inisiatif. Ada model baru yang memperkenalkan kesenjangan antara yang ideal dengan kenyataan yang ada. Kritik dan tanggapan terus ada pada model ini. Berpikir mengenai usaha, energi, dan sumberdaya untuk dimaksukkan dalam proyek 
perubahan mungkin lebih baik untuk direkomendasikan. Perubahan sering kali sulit dilihat dalam hal memulai dan menimbulkan efek negative. Manajer dituntut untuk memiliki wawasan dalam mengelola perubahan dengan membaca bebagai literatur agar bisa menjalankan perubahan dengan baik.

\section{Bibliography}

[1] Alvesson, Mats, and Stefan Sveningsson. 2008. 22 The Journal of long term care administration Changing Organizational Culture - Cultural Change Work in Progress. 